\title{
Creating Vertical Strategic Alliances: Theory and Cases from Canada's Agri-Food Sector
}

\section{Erna van Duren, Wayne Howard and Helen McKay}

\section{INTRODUCTION}

Participants in Canada's agri-food sector have been averse to vertical collaboration for too long. The sector's history of producer marketing boards that were concerned with obtaining bargaining power to redress the market power of buyers has created attitudes towards buyers and sellers that increase the risk that agri-food organizations will underestimate the advantages of vertical strategic alliances and overestimate the difficulty of building such relationships. However, in spite of the prevailing attitude among participants in Canada's agri-food sector, many organizations have nurtured vertical alliances. This paper develops a framework for understanding how vertical strategic alliances can be created and illustrates it using case studies of organizations in Canada's agri-food sector that have created successful vertical strategic alliances (VSAs). Brief descriptions of the organizations involved in the case studies and the key characteristics of their VSAs are provided in Table 1.

\section{THEORY}

A vertical strategic alliance is a voluntary relationship among buyers and sellers that is pursued for mutual gain. To create such an alliance, the participants must share the goal of achieving such a relationship, they must each have to desire to achieve it, and they must both understand and carry out the processes required to achieve it. In other words, they must develop the organizational habits that are required for a vertical strategic alliance (Covey 1989, 1991). Individual and organizational habits can be viewed as the investments that occur in a business relationship. Positive habits movc organizations toward their desired state, while negative habits move them away from their desired state.
Consequently, we consider the framework depicted in Figure 1 as being very useful for organizations in Canada's agri-food sector as they determine if and how they want to create vertical strategic alliances.

\section{GOALS (WHAT?)}

A shared understanding of what the participants in a vertical strategic alliance want from the relationship (its goal) is critical to its success. It is not essential that the participants agree on all facets of the relationship, but is important that they have a shared understanding of the relationship's main goal, and that they can accept any differences in understanding. The importance of a shared goal to the success of a VSA was evident in each of our four case studies, as was a mutual commitment to remaining separate organizations.

Campbell's Canada and Ball Packaging developed a VSA because both understood that Campbell Canada's survival as a separate corporate identity was dependent on it achieving major cost reductions. Ball understood that it would have to help Campbell cut costs by reducing the prices of its cans so that they were competitive with imports as well as helping Campbell to increase productivity in its plants. Since Campbell's accounted for a significant portion of Ball's sales, Ball shared Campbell's concern that it survive as a separate corporate identity.

McCain Foods and UFL Foods Inc. shared McCain's goal of penetrating the U.S. french fry market with a new battered product and simultaneously developing a Canadian market. UFL's product development and engineering expertise was critical to McCain's goal of constructing a $\$ 40$ million plant and having it operational at set cost targets in a short time. 
Table 1: Case Study Firms and VSA Characteristics *

\begin{tabular}{|c|c|c|c|c|}
\hline Factor & McCain Foods - UFL Foods Inc. & McDonalds Camada - Caravelle Foods & $\begin{array}{l}\text { Campbell Soup Canada -- Ball Packaging } \\
\text { Products }\end{array}$ & Kelloeg - Thompson/Cargill - Corn Farmers \\
\hline $\begin{array}{l}\text { Types of } \\
\text { Organization } \\
\text { [Business] }\end{array}$ & $\begin{array}{l}\text { McCains: major, Canadian, family owned } \\
\text { multinational [Processed Foods] } \\
\text { UFL:medium, Canadian, Family owned, } \\
\text { private company [Food Additives] }\end{array}$ & $\begin{array}{l}\text { McDonalds: Canadian subsidiary of major, } \\
\text { public U.S. owned, multinational [Fast Food] } \\
\text { Caravelle: medium, Canadian, family owned, } \\
\text { private company [Meat] }\end{array}$ & $\begin{array}{l}\text { Campbells: division of major U.S. owned } \\
\text { multinational } \\
\text { [Soups, Processed Foods] } \\
\text { Ball: Canadian subsidiary of major U.S. } \\
\text { owned public multinational [Cans \& } \\
\text { Packaging] }\end{array}$ & $\begin{array}{l}\text { Kelloggs: Canadian subsidiary of major U.S. } \\
\text { owned public multinational [Breakfast and } \\
\text { Other Foods] } \\
\text { Thompson: medium, Canadian, family } \\
\text { owned, private company [Grain elevator, } \\
\text { seeds, fertilizer] } \\
\text { Cargill: Canadian operating units in major } \\
\text { U.S. owned public multinational [Grain } \\
\text { elevators, seeds, fertilizer] } \\
\text { Corn Farmers - specifically Rol-Land Farms: } \\
\text { [Family Farm/mixed farming] }\end{array}$ \\
\hline Purpose & $\begin{array}{l}\text { product development to meet U.S. market } \\
\text { penetration targets (time, price, volume) }\end{array}$ & $\begin{array}{l}\text { quality of maintain meat supply (physical } \\
\text { characteristics, reliability, delivery) }\end{array}$ & $\begin{array}{l}\text { meet quality and cost targets that had to be } \\
\text { met in the Canadian division as result of } \\
\text { changes due to CUSTA }\end{array}$ & $\begin{array}{l}\text { maintain quality of com supply required for } \\
\text { the perfect comflake }\end{array}$ \\
\hline $\begin{array}{l}\text { Dimensions } \\
\text { Time }\end{array}$ & 2.5 years & 20 years & $\begin{array}{l}\text { Business relationship: } 50 \text { years } \\
\text { VSA: } 3 \text { years }\end{array}$ & $\begin{array}{l}\text { Business relationship: } 60 \text { years } \\
\text { VSA: } 10 \text { years }\end{array}$ \\
\hline Legal & $\begin{array}{l}\text { No contract } \\
\text { Non-equity }\end{array}$ & $\begin{array}{l}\text { No contract } \\
\text { Non-equity }\end{array}$ & $\begin{array}{l}5 \text { year "ever-green" contract } \\
\text { Non-equity }\end{array}$ & $\begin{array}{l}\text { Annual contracts: Kellogg-Thompson/Cargill, } \\
\text { Thompson/Cargill-Rol-Land Farms }\end{array}$ \\
\hline Breadth & $\begin{array}{l}\text { McCains accounts for } 5-10 \% \text { of UFL'ssales } \\
\text { UFL is among McCains' largest six suppliers }\end{array}$ & $\begin{array}{l}\text { McDonalds is Caravelle's only customer } \\
\text { McDonalds purchases all of its red meat } \\
\text { requirements in Canada from Caravelle }\end{array}$ & $\begin{array}{l}\text { Ball accounts for } 20 \% \text { of Campbell's total } \\
\text { purchases } \\
\text { Ball makes } 20 \% \text { of its food industry sales to } \\
\text { Campbells }\end{array}$ & $\begin{array}{l}\text { Kelloggs purchases } 100 \% \text { of its com } \\
\text { requirements from the two elevators } \\
\text { sales to Kelloggs account for approximately } \\
5 \% \text { of each elevator's corn sales } \\
\text { Rol-Land's proportion of sales to Kelloggs } \\
\text { varies year to year }\end{array}$ \\
\hline Depth & $\begin{array}{l}\text { sharing of critical marketing, cost and } \\
\text { technical information }\end{array}$ & $\begin{array}{l}\text { relationship is as close as it can be without } \\
\text { being vertical integrated }\end{array}$ & $\begin{array}{l}\text { sharing of a wide range of information relating } \\
\text { to day-to-day operations, technical issues, } \\
\text { product and package design and administrative } \\
\text { information. }\end{array}$ & $\begin{array}{l}\text { co-ordination of scheduling and sharing of } \\
\text { information relating to quality and some } \\
\text { aspects of price } \\
\text { closest to open market }\end{array}$ \\
\hline
\end{tabular}

* For further discussion see van Duren, E, Howard, McKay H. Progressive Buyer-Supplier Relationshins: Case Studies. Agri-Food Competitiveness Council, Guelph, Ontario, March 1993. 

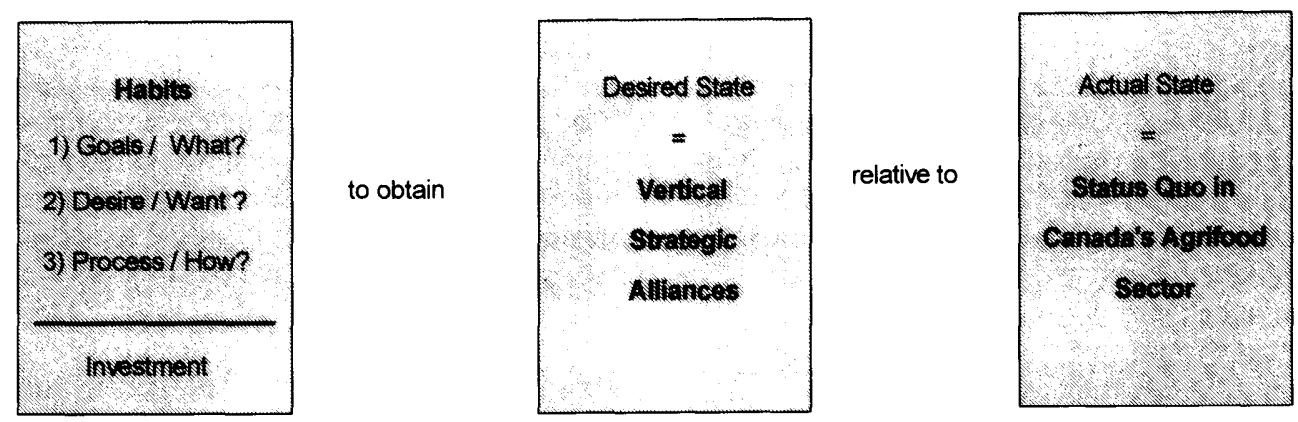

Figure 1. Framework for creating vertical strategic alliances in Canada's Agri-Food Sector

McDonald's Canada and Caravelle Foods shared the goal of providing consumers with quality beef patties in McDonalds products. As a dedicated supplier, all of Caravelle's sales and strategic efforts are geared to helping McDonalds produce quality beef products. Similarly, McDonalds actively involves its dedicated suppliers in pursuing its strategic goals; e.g., all suppliers participate in McDonald's environmental initiatives.

Kelloggs, the grain elevators it deals with (W. G Thompson and Sons and Cargill) and several southwestern Ontario corn farmers share Kellogg's goal of making a perfect golden corn flake, and each participant is willing to put in extra effort to make this possible.

In cach of thesc four case studies, the participants in the VSA had a shared goal although the importance of this goal to the overall success of any one of the participants varied. In each VSA the goal was concerned with creating the means for competing, not just short-term gains through positioning in the market. Also, in each case, a clear understanding of the limits of the relationship was evident.

\section{DESIRE (WANT?)}

The desire to obtain the goals of the VSA is critically important to its success; it provides the relationship with it energy and commitment. This type of desire was evident in each of the case studies that we examined. Both partners in these case studies were dedicated to meeting their partners' wishes. Although this behaviour is stronger for the supplying firms, it was also demonstrated by buyers as evidence that they did not wish to vertically integrate backwards into their partner's business.

In the Campbell Soup - Ball Packaging relationship, the significant transformation in corporate culture that materialized after the passage of the Canada-U.S. Trade Agreement (Duhaime) provided much of rationale and momentum for the close relationship between these firms, as did Campbell's survival as a separate corporate identity. Campbell's desire to be the "Best food company in North America" through its "fastest gate to plate" strategy induced employees to be more empowered and innovative. This change, along with Campbell and Ball's shared commitment to total quality management, fueled their VSA.

McCain Foods and UFL Foods Inc. were both committed to doing whatever it took to get McCain's new plant operational. UFL demonstrated its commitment to the relationship's success through having its Chairman make the initial presentation to McCain personally. McCain's wish to pursue a VSA simply by attempting a relationship with a supplier that was markedly different from the norm.

McDonald's Canada and Caravelle Foods are both highly motivated to make their relationship work and are driven by providing a quality product to the consumer. Early in their twenty year relationship Caravelle demonstrated its commitment to meeting McDonald's needs by providing exactly according to specification without asking questions, delivering beef patties 24 hours a day - 7 days a 
week - 52 weeks per year, and eventually building a dedicated plant for McDonalds on only a verbal agreement. McDonalds is highly committed to the success of its dedicated suppliers and assures them of cost plus markup because it feels such an arrangement provides for better quality over the long-run than vertical integration; a subsidiary might be tempted to cut corners in order to reduce costs without fear of losing the business.

Kelloggs, the grain elevators that it deals with and the southwestern Ontario corn farmers who choose to meet Kellogg's requirements are all willing to put in the extra effort required to deliver the corn needed to make the perfect golden cornflake.

In each of our case studies the firms involved in the VSAs were committed to making that relationship work and remaining separate organizations. Each organization was dedicated to meeting its partner's wishes, and generally doing "whatever it takes to get the job done".

\section{PROCESSES-HOW?}

The process for creating a vertical strategic alliance is intertwined with the goals and the motivation for creating such a relationship but is akin to building trust. Building trust, in turn, involves competency and character. Competency includes having the skills and expertise to achieve the goal of the alliance. It is closely related to having the desire to take the action required to meet that goal. Competency can be thought of as the technical business skills required to meet the VSA's goals. Building trust also entails a character component, which can also be thought of as the interpersonal abilities required to meet the expectations of the alliance. Partners in a VSA do not have to contribute character and competence to equal degrees for a successful relationship. Rather complementary interests which facilitate giving, taking and mutual gain appear to work well. Our case studies illustrate the role of character and competence in creating the trust required for a successful VSA.

In Campbell Soup's and Ball Packaging's relationship, Ball provided much of the technical expertise that enabled Campbell to meet its cost reduction targets. Ball provided all the technical support that Campbell required for depalletizing, can-handling and sealing. By being in the Campbell plant on a semi-regular basis Ball staff helped to minimize down-time as well as providing advice which allowed Campbell to reap further productivity improvements. Joint efforts in product and package design also resulted in the cost reductions that were so critical a component of the relationship's goals and motivation.

Open and honest communication, especially on the part of Campbell Soup management staff who had to change the way they did business with suppliers, was also critical to the success of this relationship. When faced with the strategic imperative of cutting cost, Campbell's honestly informed their suppliers that not all of them would be doing business with Campbell's in two years. Subsequently, Campbell's shared key strategic and cost information with those firms that met the performance criteria required to be preferential suppliers, thereby facilitating the two companies' joint cost reduction efforts.

The vertical alliance between McCain Foods and UFL Foods Inc. was given encouragement early by the favourable impression of having UFL's chairman of its family owned company give the initial presentation to McCain's senior management; also largely family members. This action was perceived as demonstrating UFL's character, as well as its commitment to the success of the venture. In this relationship McCains has been particularly open with key strategic, cost and technical information which enabled UFL technical experts to help marketing and technical staff at McCains meet the joint goal of penetrating the U.S. market at a given price level. For McCains, the openness and honesty it has with UFL required abandoning some longheld behaviours with respect to suppliers.

McDonald's Canada and Caravelle Foods share all information required to meet McDonald' goal of providing quality beef patties in their various burgers. Caravelle has always met McDonald's specifications with- 
out question, on time, and as their dedicated relationship developed Caravelle assumed a growing role in product development. Caravelle now has test kitchens identical to those in McDonald's restaurants. The firms are completely open and honest with each other. McDonald's uses open book costing with its suppliers since it feels that ensuring that their suppliers have a fair profit margin promotes better quality since a subsidiary might be tempted to cut corners. The companies are interdependent in the behaviours and actions they pursue to satisfy McDonalds' customers.

Kellogg's and the grain elevators that handle the special variety of corn required for Kellogg's cornflakes are honest with the farmers with respect to whether their corn will meet Kellogg's requirements, a bchaviour that develops trust with the farmers who now know that Kelloggs will buy their southwestern Ontario corn whenever possible. Only in the summer of 1992, when rain devastated much of the southwestern Ontario corn crop, did Kelloggs source their corn elsewhere. Since it informed the farmers early of this decision, many of them were able to sell their corn at better than typical prices. To encourage farmers to grow Kellogg's special variety of corn, Kellogg arranges plant tours enabling farmers to learn that Kellogg's workers view themselves as producers of food, just like the farmers.

The specifics of the processes that organizations wishing to develop vertical strategic alliances vary by their goals, but during the evolution of such relationships the involved organizations build trust among themselves. For some organizations building this trust entails using their technical business skills to contribute to meeting the alliance's goals, while for others it is more a matter of sharing more business information than has typically been the case. Complementarity of business skills allows both organizations to contribute to the success of the alliance.

\section{CONCLUSIONS AND PUBLIC POLICY IMPLICATIONS}

The framework and case studies provided in this paper lead to several conclusions and suggest implications for public policy. However, the case studies clearly suggested that government policy plays a minor role in inhibiting or enhancing the development of VSAs; the really important factors are within the control of the participants.

Shared goals are important to a successful VSA, but it is essential that this goal be concerned with creating the means for competing, not only reaping the benefits of market positioning or market power. The former type of goal builds business synergies, generates mutual growth and fosters interdependence because all participants in the VSA are contributing to the relationship. Many of the organizational forms that have been encouraged by Canadian agri-food policy are not motivated by goals concerned with creating the means to compete. Rather, by encouraging the creation and use of market power, Canadian agrifood policy has undermined agrifood firms' needs to pursue competitiveness creating relationships.

The desire to create a VSA is also integral to its success. This desire requires a demonstrated commitment to making the relationship work, and a dedication to meeting a partner's wishes. Again, the institutions and behaviours encouraged by Canadian agri-food policy have atrophied businesses' incentives to be customer driven. Many are production driven and assume the curious notion that the customer "needs to be educated" and that he/she should be provided as little value for his/her money as the system will tolerate. This mindset occurs even in industries that Canadian agricultural economists have traditionally characterized as market driven. For example, the Canadian Wheat Board did not want to change its grading-classification scheme to meet the wishes of Italian durum buyers who indicated they would buy substantial volumes of Canadian product if their request was accommodated (Braga).

The process of building trust is essential to organizations that desire to create a VSA and have shared goals. Trust is a highly ethical behaviour which is a form of human capital that reduces transactions costs and creates benefits which provide forward momentum 
for the VSA. Trust can be developed consciously since it requires an interdependence, or complementarity, of competence and character.

In our case studies, as well as other strategic alliances examined in the literature, a key to being able to use the business skills of another organization in meeting one's objectives through a collaborative relationship has been abandoning the mindset, "that was not invented here". North American firms' abysmal records at product development demonstrate that there is still a challenge in this area. Similarly, agri-food research and development policy makers should examine how they can assist in improving the commercialization link of the research and development process. They could begin by offering additional support to firms pursuing alliances in order to build their business competences.

Character in a strategic alliance consists very much of being open and honest with any information that is important to achieving the goals of the relationship, and in turn honouring its confidentiality. It is also a matter of doing what you say you are going to do meeting expectations. In our case studies, all participants practised this behaviour in their VSAs.

Developing the habits required to build a successful VSA is a challenging task, but if pursued successfully these collaborative relationships can be created in any type of industry, market, and among any types of organizations. The biggest challenge for any organization embarking on the process of building a VSA, and one that was clearly articulated by nearly all the participants in our case studies was abandoning the mental model "that's not how we do business around here". The implications of this challenge for Canadian agri-food policy are obvious.

\section{REFERENCES}

Braga, F. and R. Raffaelli. 1993. Implications of a Changing Commodity Quality Definition: The Case of Canadian Durum Wheat Exports to Italy. Paper Presented at the International Agribusiness Management Association Annual Meeting, San Fransisco, CA.

Covey, Stephen R. 1991. Principle Centered Leadership. Simon and Schuster, New York.

Covey, Stephen, R. 1989. The Seven Habits of Highly Effective People. Simon and Schuster, New York.

Duhaime, K. 1993. Campbell Soup Company Ltd. George Morris Centre, Guelph, ON.

Howard, W., E. van Duren and H. McKay. 1993. Vertical Strategic Alliances in Canada's Agrifood Industry: Theory and Cases. Paper Presented at "Agricultural Markets: Mechanisms, Failures and Regulations" at Institut D'Economie Industrielle, Toulouse, France, Oct. 21-23, 1993.

van Duren, E., W. Howard and H. McKay. 1993. Progressive Buyer-Supplier Relationships: Case Studies. Agri-Food Competitiveness Council, Guelph, ON.

van Duren, E. and H. McKay. Forging Strategic Alliances in Canada's Agri-Food Sector: A Framework for Analysis and Action. Discussion Paper DP93/01, Department of Agricultural Economics and Business, University of Guelph, Guelph, ON. 